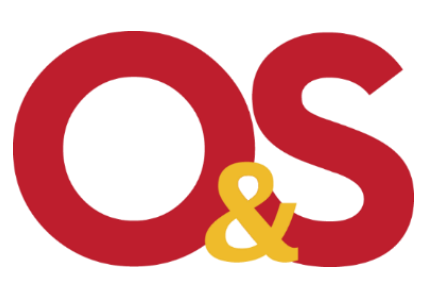

Journal Organizações \& Sociedade

(C) Authors 2021

DOI 10.1590/1984-92302021v28n9600EN

ISSN 1984-9230

\title{
Editorial
}

www.revistaoes.ufba.br

NPGA, School of Management

Federal University of Bahia

\section{Symbolic Impact of Research}

\author{
Josiane Silva de Oliveira ${ }^{a}$ \\ Eduardo Paes Barreto Davel ${ }^{\text {b }}$ \\ a Universidade Estadual de Maringá, Maringá, Brazil \\ b Universidade Federal da Bahia, Salvador, Brazil
}

\begin{abstract}
Most understandings obtained from the numerous debates about the impact of scientific research on society are concentrated on the economic, social, cultural and technological dimensions, thus urging for a deeper understanding of the impact on its cultural and, particularly, symbolic dimensions. Every research result bears a symbolic weight that will impact organizations and society. Thus, researchers must reflect on how to produce results while aware and sensitive of the symbolic impact they may cause. Symbolic impacts are decisive for understanding the subtle, deep and structuring value that research results have in developing and transforming society and organizations.
\end{abstract}

Keywords: impact; research; symbolism.

\section{Introduction}

The debate on the impact of scientific research on society is at the center of attention nowadays, recurrently addressed based on the economic, social, governmental, organizational, technological, cultural, and educational dimensions. The cultural dimension of research impact is confined to stimulating and enriching cultural production and preserving the cultural heritage of nations (Bornmann, 2012; Brook, 2018), thus urging for a deeper understanding of such impact on society cultural and, particularly, symbolic dimensions. Given that symbolism is a key concept in helping us understand ourselves as a society (Bourdieu, 1989; Cassirer, 2001, 2004, 2011; Cohen, 
1985; Eliade, 1980; Goldschmidt, 1990; Hamlin \& Krois, 2004; Jung, 1968; Scheffler, 1997), how come we fail in thinking and considering the impact of research in its entirety upon the symbolic realm?

Discussions about scientific research impacts are often limited to understanding the need for their measurement, so that causal relationships or escalation types are the most used strategies in conducting such debate (Sandes-Guimarães \& Hourneaux, 2020). However, some impacts are predominantly subjective and, although not measurable, enable us to fully apprehend how scientific production deeply impact our cultural practices and help developing a sense of social life. After all, the way science relates to identifying problems, discussing, and offering responses to society is directly associated with how society relates to science from a symbolic perspective.

Who produces scientific knowledge, how it is produced, and what is produced must also be considered in this equation. Our scientific practices, which are also symbolic/cultural practices, are means through which both societies and organizations represent and see themselves represented. Thus, besides thinking about problems, practices, and results that generate economic, financial, and social impacts, we must consider the symbolic impacts of these productions. Survey results may significantly alter perceptions about our study field and objects.

By deeming our scientific practices as cultural practices (Pickering, 1992; Taylor, 1994), we emphasize that society can and must identify itself with its scientific production, which does not mean reproducing the common sense, nor providing answers that stabilize our social relations. Our scientific production must be grounded on creating symbols and symbolic representations that cause individuals to rethink, question, and rupture with certain oppressive representations, knowledge, and worldviews. That means to say that every research result carries a symbolic weight that will have an impact on organizations and society, so that researchers must reflect upon how to produce results while aware and sensitive of the symbolic impact they may cause.

We must think scientific production through its symbolic impact on society (Haro, 2017; Koch \& Vanderstraeten, 2018; Minayo, Gomes \& Silva, 2020; Vessuri, Guédon, \& Cetto, 2014). Thus, this editorial seeks to stress the importance of thinking the impact of scientific research upon the symbolic dimension of societies and organizations. With that, we intend to expand and deepen knowledge on the impacts of research and its applications in the regulatory bodies of science.

\section{The symbolic dimension of organizations and society}

In regard to the understanding that societies and organizations are constituted by symbols, symbolism has been the subject of many studies on anthropology, social sciences, and organization. It refers to the intersubjective processes substantiating how people produce, understand, and interpret the context in which they are inserted, molding their social practices (Geertz, 1978). As such, symbolism is not just about the abstract dimension of concrete life, but rather about how reality is interpreted and turns into something concrete. Symbolic production is producing structural and profound meanings regarding our living world, thus granting us some sort of agency.

In scientific production, the symbolic dimension of society and organizations points out, consciously or unconsciously, how they are systematized from the analytical perspective of sciences. The images, senses, and meanings that we mobilize to systematize our reflections and results when 
conducting a research show the intersubjective processes based on our agency within this reality. For example, if such mobilization operates in the sense of reinforcing stereotypes, the symbolism inherent to this production may foster what Collins (2016) called controlling images. These images aim to reproduce a social organization grounded on power relations, articulated by relations of domination and subordination. Thus, our cultural practices - structurally marked by power relations - substantiate the symbolic dimension of society and organizations in our scientific production, explaining the importance of reflecting upon the symbolic impacts arising from research results.

Organization studies deem symbolism as the foundation of organizational dynamics (Boje, 2002; Carrieri \& Saraiva, 2007; Pondy, Frost, Morgan, \& Danbridge, 1983; Turner, 1990, 1992), a theorizing approach (Hatch \& Cunliffe, 2006), the language of their relations (Pratt \& Rafaeli, 2001), a source of value creation (Ravasi \& Rindova, 2008), and a management action (Pfeffer, 1981). In other words, research results may symbolically affect organizations in their operating dynamics, work relationships, value creation processes, and in the action of their managers. Alcadipani (2014) showed how intersubjective relationships with study participants mediate the symbolic impacts of conducting an ethnography. According to the researcher, the fear of symbolic impacts on daily activities may preclude the study performance regardless of formal authorization for fieldwork. He also argues that a study conducted in a Brazilian communication agency was hampered due to the identification, decoding, and use of social relations in the operational area against this group by the company management. Regarding a public security organization, the fear was motivated by the lack of control over the study impacts and the organization image. That is, organizations and society worry about how they are going to be portrayed in publications - a concern related to the symbolic impacts these may have on them.

The mean through which society is depicted within the scientific field, and not only as an study object, also raises concern. A thesis elaborated by Cardoso (2014) sparks the debate on this topic by analyzing when non-white cease to be research objects to feature as protagonists. Such positioning shift is reflected not only in the analyses results, but also in how society perceives itself as a community that occupies different social spaces. In his study, white people who often define non-whites racialization processes as the study object had to play the role they always assigned to "others." By doing that, the author stimulated a symbolic reflection upon who we are in structural terms within the scientific field and society. Likewise, the research seeks to symbolically impact these intersubjectivities by highlighting the concreteness of reality, as it defines who we are as scientific field, society, and organizations.

The symbolic dimension is not limited to contextualize research results based on the analyzed reality - it embraces apprehending instabilities and questioning who we are as a society and organizations. Talking about symbolism entails discussing the relevance of understanding the intersubjective impacts of academic research, highlighting instabilities that show relations of power, domination, and subordination. Surveys directly impact these instabilities. Thus, besides addressing the technological, social, and economic impacts of research, their symbolic dimension must also be considered, given that research results will evince or potentially transform the organization and social daily life. 


\section{Symbolic impact of academic research}

Part of the academic research is the mobilization of symbols, senses, and meanings. Apart from producing empirical evidence, this process must outline our ability to mobilize intersubjectivities in daily activities, which is only possible if we understand academic research in the context of social dynamics. In that sense, the symbolic impact of academic research refers to this ability of mobilizing intersubjectivity so that people can see themselves as participants of the scientific practice. Some dimensions may be assessed for understanding this impact, the first of which is language. The language used by the researcher may differ from that commonly employed by the research field and, as intersubjectivities are constructed, languages must be articulated.

The material dimension of the research (the human body or even an object) is yet another assessable dimension. In this regard, it is important to restate that the intersubjective construction with the research field may alter how we relate to ourselves and to the surrounding environment. Likewise, our bodies may experience several changes when we conduct field research (Almeida \& Flores-Pereira, 2013). From walking to eating habits, from religious practices to the "team of the heart,", conducting a survey alter the values and references of both researchers and participants. Ignoring these profoundly symbolic elements is to silence the "pulse" that gives meaning and symbology to our work as researchers. How often do we think about what remains from the field research? What changes within the organization after our visit? Discussing the symbolic impacts of academic research presupposes thinking procedurally about our activity and the consequences after we "leave."

We may cite as an example the development of the CoronaVac vaccine by the Butantan Institute in the pandemic context in Brazil. Besides the slogan "The Brazilian vaccine," this scientific publication was disseminated and symbolic constructed based on the aesthetics, language, and imagery of Funk - a Brazilian musical genre that still encounters prejudice in the scientific field and even in part of the society (Cymrot, 2011). Through the symbolism of a young man from the Brazilian urban periphery, MC Fioti, wearing a white coat and doing science with one of the main research institutes worldwide, the dissemination process of the CoronaVac evinces a meaning displacement regarding who does science and the relationships that must be established for this publication to "go beyond the article."

Society, as a whole, must comprehend its role in the developed research and, for that, individuals must be aware of all contradictions, controversies, and conflicts within it. We may observe the symbolic impacts of scientific publications in the changes promoted by them with and for the general public and for those who are historically considered part of this field, as well as in their underlying mechanisms. A woman publishing about computer programming, a black person addressing topics not centered in racial relations, a trans woman discussing subjects beyond sexuality - these examples illustrate how scientific publications may also incur a symbolic impact of breaking stereotypes that are (re)produced by the scientific field. Publishing and/or disseminating the results of scientific research on a channel specializing in funk, samba, or pagode is yet another example of this symbolic impacts.

In a context where the validity of science has been questioned based on questionable assumptions (including by country leaders), discussing the symbolic impacts of scientific research challenges us to understand how to extrapolate our results from a mere "article" publication. 
Rather, such debate should spark the understanding of scientific publication as a means of producing knowledge that is accessible and accessed by the entire community. Moreover, we should also recognize that scientific practice is but a symbolic practice and, as such, must be part of everyday life. This is because intersubjective relations are not solely concerned with the abstract dimension, but also on apprehending our concrete reality, just as symbolism is not solely concerned with abstraction, but also with sociocultural production.

\section{References}

Alcadipani, R. (2014). Confissões etnográficas: Fracassos no acesso a organizações no Brasil. Revista Brasileira de Estudos Organizacionais, 1(1), 64-87. doi:10.21583/24474851.rbeo.2014.v1n1.31

Almeida, D. D., \& Flores-Pereira, M. T. (2013). As corporalidades do trabalho bailarino: Entre a exigência extrema e o dançar com a alma. Revista de Administração Contemporânea, 17(6), 720-738. doi:10.1590/S1415-65552013000600006

Boje, D. M. (2002). Organizational symbolism. In A. Sorge (Ed.), Organization (pp. 358-367). London: Thompson Learning.

Bornmann, L. (2012). What is societal impact of research and how can it be assessed? A literature survey. Journal of the American Society for Information Science and Technology, 64(2), 217233. doi:10.1002/asi.22803

Bourdieu, P. (1989). O poder simbólico. Rio de Janeiro, RJ: Bertrand Brasil.

Brook, L. (2018). Evidencing impact from art research: analysis of impact case studies from the REF 2014. The Journal of Arts Management, Law, and Society, 48(1), 57-69. doi:10.1080/10632921.2017.1386148

Cardoso, L. C. (2014). A branquitude acrítica revisitada e a branquidade. Revista da Associação Brasileira de Pesquisadores(as) Negros(as), 6(13), 88-106.

Carrieri, A. P., \& Saraiva, L. A. (Eds.). (2007). Simbolismo organizacional no Brasil. São Paulo, SP: Atlas.

Cassirer, E. (2001). A filosofia das formas simbólicas: A linguagem. São Paulo, SP: Martins Fontes.

Cassirer, E. (2004). A filosofia das formas simbólicas: O pensamento mítico. São Paulo, SP: Martins Fontes.

Cassirer, E. (2011). A filosofia das formas simbólicas: Vol. 2: Fenomenologia do conhecimento. São Paulo, SP: Martins Fontes.

Cohen, A. P. (1985). The symbolic construction of community. London: Routledge.

Collins, P. H. (2016). Aprendendo com a outsider within: a significação sociológica do pensamento feminista negro. Sociedade e Estado, 31(1), 99-127. doi:10.1590/\$0102-69922016000100006

Cymrot, D. (2011). A criminalização do funk sob a perspectiva da teoria crítica (Dissertação de Mestrado). Universidade de São Paulo, São Paulo, SP. 
Eliade, M. (1980). Images et symboles: Essais sur le symbolisme magico-religieux. Paris: Gallimard. Geertz, C. (1978). A interpretação das culturas. Rio de Janeiro, RJ: Zahar.

Goldschmidt, W. (1990). The human career: The self in the symbolic world. Cambridge: Blackwell.

Hamlin, C., \& Krois, J. M. (Eds.). (2004). Symbolic forms and cultural studies: Ernst Cassirer's theory of culture. New Haven: Yale University Press.

Haro, F. A. (2017). O impacto de (não) ter impacto: Para uma sociologia crítica das publicações científicas. Revista Crítica de Ciências Sociais, 113, 83-106. doi:10.4000/rccs.6659

Hatch, M. J., \& Cunliffe, A. L. (2006). Organization theory: Modern, symbolic and postmodern perspectives. Oxford: Oxford University Press.

Jung, C. G. (1968). Man and his symbols. New York: Dell Publishing.

Koch, T., \& Vanderstraeten, R. (2019) Internationalizing a national scientific community? Changes in publication and citation practices in Chile, 1976-2015. Current Sociology, 67(5), 723-741. doi:10.1177/0011392118807514

Minayo, M. C. S., Gomes, R., \& Silva, A. A. M. (2020). 25 anos de ciência para construção do SUS. Ciência \& Saúde Coletiva, 25(3), 780. doi:10.1590/1413-81232020253.34952019

Pfeffer, J. (1981). Management as symbolic action: The creation and maintenance of organizational paradigms. Research in Organizational Behavior, 3, 1-52.

Pickering, A. (Ed.) (1992). Science as practice and culture. Chicago: University of Chicago Press.

Pondy, L. R., Frost, P. J., Morgan, G., \& Dandridge, T. C. (Eds.). (1983). Organizational symbolism. Greenwich: Jai Press.

Pratt, M. G., \& Rafaeli, A. (2001). Symbols as a language of organizational relationships. Research in Organizational Behavior, 23, 93-132. doi:10.1016/S0191-3085(01)23004-4

Ravasi, D., \& Rindova, V. (2008). Symbolic value creation. In D. Barry \& H. Hensen (Eds.), The SAGE Handbook of New Aproaches in Management and Organizations. Thousand Oaks: Sage.

Sandes-Guimarães, L.V. D., \& Hourneaux, F., Jr. (2020). Research impact - what is it, after all? Editorial impact series part 1. RAUSP Management Journal, 55(3), 283-287. doi:10.1108/rausp-07-2020-202

Scheffler, I. (1997). Symbolic worlds: art, science, language, ritual. Cambridge: Cambridge University Press.

Taylor, C. A. (1994). Science as cultural practice: A rhetorical perspective. Technical Communication Quarterly, 3(1), 67-81. doi:10.1080/10572259409364558

Turner, B. R. (Ed.) (1990). Organizational symbolism. Berlin: De Gruyter.

Turner, B. R. (1992). The symbolic understanding of organizations. In M. Reed \& M. Hughes (Eds.), Rethinking organization. Thousand Oaks: Sage.

Vessuri, H., Guédon, J. C., \& Cetto, A. M. (2014). Excellence or quality? Impact of the current competition regime on science and scientific publishing in Latin America and its implications for development. Current Sociology, 62(5), 647-665. doi:10.1177/0011392113512839 


\section{Authorship}

\section{Josiane Silva de Oliveira}

Ph.D. in management from the Universidade Federal do Rio Grande do Sul. Professor at the Universidade Estadual de Maringá and in the Graduate Program in Management at the Universidade Federal de Goiás, Brazil. Associate editor of the Organizações \& Sociedade journal, axis "organizations, theory and methods". Researches and publishes in the field of practice-based studies, black feminism, ethnography, culture, and arts in organization studies.

E-mail: oliveira.josianesilva@gmail.com

ORCID: https://orcid.org/0000-0002-7085-8921

\section{Eduardo Paes Barreto Davel}

Ph.D. in management from École des Hautes Études Commerciales de Montréal (Canada), with a post-doctorate research in Management from Nova School of Business and Economics at Universidade Nova de Lisboa (Portugal). Professor at the School of Management at the Federal University of Bahia, Brazil. Editor-in-chief of Organizações \& Sociedade journal. Researches and publishes on cultural entrepreneurship, creative process management, teaching, methods, learning, culture, and aesthetics in organizations.

E-mail: davel.eduardo@gmail.com

ORCID: https://orcid.org/ 0000-0003-0610-6474

\section{Authors' contributions}

First author: conceptualization (equal), investigation (equal), writing-original draft (equal).

Second author: conceptualization (equal), investigation (equal), writing-original draft (equal).

O\&S is signatory to DORA (The Declaration on Research Assessment) and to COPE (Committee on Publication Ethics).

$$
\begin{aligned}
& \text { Signatory of } \\
& \text { DORA }
\end{aligned} \text { G } \mid \text { O } \mid \text { P } \mid \text { E } \mid \text { gommitien on publication ethlos open access }
$$

